\title{
Community's Social Construction on Covid-19 Patients with Supervision in Surakarta Indonesia
}

\author{
Argyo Demartoto*, Yuyun Sunesti , Bagus Haryono, and Aris Arif Mundayat \\ Department of Sociology, Universitas Sebelas Maret, Indonesia
}

\begin{abstract}
Negative stigma labelled against Covid-19 patients and health workers can worsen Covid-19 management situation. Therefore, this research aimed to analyze Surakarta people's interpretation on Covid-19 patient and their social construction process on Covid-19 patient in Surakarta Indonesia. This qualitative research with phenomenological research employed purposive sampling technique. Research informants consisted of Surakarta people, Pulmonologists and Nurses in Dr. Moewardi Surakarta Hospital, Chief Executive of Covid-19 Management Acceleration Task force of Surakarta City, etc. Online observation, indepth interview, and documentation with internet media were used to collect primary and secondary data. Method and data source triangulations were used to validate data. Interactive model of analysis was conducted using Berger's Social Construction theory. Surakarta People's social construction on Covid-19 positive patients passed through some process: Externalization process indicated with Surakarta people's early perception on Covid-19 as a new disease known poorly, thereby generating fear and ignorance among them; Objectification process showing people with varying perspectives on Covid-19 positive patients; and Internalization process finding the subjective reality of Surakarta People on Covid-19 patients affected by objectification stage, later creating interpretation on individual or group having ever interacted with this virus patient.
\end{abstract}

Keywords: social construction, Covid-19-positive patient

\section{Introduction}

Considering CSSE data of Johns Hopkins University, at least 5.501.037 persons per May 26, 2020, have been infected with Covid-19 throughout world with 361.484 deaths [1]. Meanwhile in Indonesia, Kementerian Kesehatan Republik Inodnesia per May 26, 2020 reported 23,165 people positively infected with 1.418 deaths. From the data, case fatality rate (CFR) of Covid-19 in Indonesia is $6,60 \%$ [2]. The figure is higher than the

*Corresponding author: argyodemartoto fisip@staff.uns.ac.id 
world's, 6,08\%. All community elements should comply with the virus transmission prevention protocol [3]. Although in reality some people still disobey and even underestimate the prevention protocol.

Amid Covid-19 pandemic, a social phenomenon arises potentially exacerbating the situation, negative social stigma or association against an individual or a group of individuals with certain symptoms or developing certain disease [4]. They are labelled, stereotyped, discriminated, treated differently, and/or experiencing status insult due to their association with a disease. As a new disease, many facts have not been known about Covid19 pandemic. Moreover, human beings tend to fear of something unknown and associate the fear more easily with other/different groups. It is this that generates social stigma and discrimination against certain ethnic and persons considered as having relation to this virus $[5,6]$.

Confusion, anxiety, and fear felt are understandable, but it does not mean that prejudice is allowed against patients, families, nurses, or those with Covid-19-like symptoms. If it is left continuously, consequently social stigma will make people potentially hide their disease symptom to prevent discrimination, to avoid help and examination because they fear their disease will be known by others [7]. This condition enables people to transmit disease to others. Therefore, World Health Organization (WHO) states that stigma is more dangerous than the virus itself [8].

Social construction is an interpreting process conducted by each individual on environment and aspect beyond itself, subjective meaning of objective reality inside the one's consciousness of undertaking his/her daily activity. Social reality is something the presence of which is dependent on each individual. Externalization is self adaptation to socio-cultural world as human product. Human beings keep growing and developing both biologically and socially; therefore, they keep learning and working to build its life sustainability. Externalization is a process of actualizing human selfness into world, in either physical or mental activity. It has been an anthropological requirement that humans always actualize themselves where they live. They cannot be perceived as a closure separable from their outside world. Objectification is the result achieved from human externalization activity, either mentally or physically. The daily life reality is objectified or perceived by human beings as objective reality. Objectification is the achievement of human activity externalized and then achieved objective characteristic. Internalization is the process of reabsorbing objective world into consciousness in such a way that subjective individual is affected by social world structure [9], Community as a subjective reality implies that objective reality is interpreted subjectively by individual. Therefore, this research aims to analyze how Surakarta people interpret Covid-19 patients and the community's social construction process on Covid-19 patients.

\section{Method}

This study was a qualitative research with phenomenological approach to give a comprehensive understanding based on community's perspective on Covid-19 positive patient. The research was conducted in Surakarta, Indonesia. Corresponding to the objective of research, the sampling technique used was purposive sampling [10]. Unit of Analysis consisted of key informants including Chief Executive of Covid-19 Management Acceleration Task force of Surakarta City, Chairperson of Surakarta City's Health Office, Head of Disease Control and Environmental Health Division of Surakarta City's Health Office; main informant including Surakarta People, Patients with Supervision (Pasien Dalam Pengawasan / PDP), People with Monitoring (Orang Dalam Pemantauan / ODP), surrounding neighbour, and family of Covid-19-positive patients; and supporting informants including pulmonologists and nurses in Dr. Moewardi Surakarta Hospital. 
Through computer, smartphone, social media, and etc, in the form of text chat, video call, phone call, email or Google form, the author collected primary and secondary data related to research object using online observation, interview, and documentation with internet media [11, 12]. Resources, reference from other researchers, and information screening using various methods were used as source and method triangulations to validate the data. Data was analysed using Berger's Social Construction theory and Interactive Model of analysis from Miles and Huberman [14, 15].

\section{Result}

Covid-19 transmission chain has not been broken until today. The virus spreads so rapidly and massively that makes the people paranoid. Furthermore, the problem becomes complicated when this pandemic has systemic impact, in which the presence of pandemic concerns not only health problem only, but also in-depth social-economic misery. If there has been no rapid and appropriate management in long term, it will potentially results in social outbreak within society. Sociologically, such abnormal situation will indeed generate collective behaviour, massive panic. As a result, social space becomes clouded and segmented easily. Social vulnerability usually can easily result in suspicion and social prejudice amid critical situation uncertainty today.

The emergence of social stigma within society has been a challenge in breaking Covid19 transmission chain. Currently people still categorized into observation and supervision process (ODP and PDP), moreover those confirmed positively infected with Covid-19, are often stigmatized socially by the society. They are labelled, stereotyped, discriminated, and treated differently because their status is considered as associated with this pandemic disease.

Some Surakarta people still stigmatize Covid-19 patients, thereby makes the medical personnel's management duty difficult in the field. Stigma is not merely an attitude or a behaviour making individual or community circumstance less good. It can be seen from the incidence of declination and expulsion against 3 nurses in one of Regional Hospitals in Surakarta by the owner of boarding house through short message in WhatsApp (WA) application because the hospital where the nurses work become the referral hospital for Covid-19.

Not only oppressive scorn but also excessive paranoid is reflected on some people in Surakarta. Some people's avoidance is understandable because they worry, are panic or afraid of. However, if it has been excessive, at certain point it instead results in a new bigger problem. Otherwise, our relatives becoming ODP, PDP, and positive patient, including medical personnel dealing with Covid-19 case needs support, particularly from closest people like family and surrounding neighbour. Even small support will give the feeling of secure and comfort, thereby accelerating the recovery process. But, the support should keep considering the protocol recommended by government.

On the one hand, government wants to be transparent in informing the identity of Covid-19 patients to trace the contact as the attempt of finding Covid-19 positive cases (tracing) in the field. If some neighbours develop Covid-19-like symptoms, they will be alienated, isolated, and bullied. Their family will also be bullied and alienated. The attitude is actually regretted because many people are still emphatic with Covid-19 patients. The stigma will result in marginalization and in turn exacerbate an individual's health status and wellbeing degree. Therefore, the transparency of information on identity of Covid-19 patients should be tightened.

The educating-socializing function of central-to-village governments should involve religious and society leaders playing significant role in removing stigma. The people should understand that as long as they perform physical distancing, wear mask, wash hand 
routinely, and eat nutritious food, they will be safe from the risk of being infected with Covid-19.

The successful management of Covid-19 pandemic can be measured through the broken transmission chain, because the prevention of stigmatization is an important requirement to realize it. For that reason, to prevent social stigmatization against those with risk of being or those infected with Covid-19 positively, social control attempt should be taken by building collective consciousness.

The participation of social agents such as family, RT/RW (Neighbour Association/Citizen Association), community, NGO, and media is very important to build collective consciousness to educate the community continuously and to give them an understanding in order not to stigmatize Covid-19 patients or their family. It means that the social agency can be catalyst in building consciousness and changing the community's behaviour into discipline one complying with the protocol of Covid-19 transmission prevention, and to strengthen the message of reducing stigma, building emphatic attitude to the stigmatized people.

\section{Discussion}

Social construction on Covid-19 pandemic condition is affected by community's knowledge on the reality occurring, thereby tends to generalize, and in turn to generate negative stigma that those infected with virus will inhibit everything [8]. Discrimination behaviour case in people with monitoring (ODP), patients with supervision (PDP), and suspect occurs more widely, so does the undue discrimination. Three nurses working in a Regional Hospital of Surakarta are expelled by the owner of boarding house because the owner is afraid of being infected with the virus. Similarly, a declination occurs against the funeral of Covid-19 patient corpse by a number of villagers. ODP, PDP, and nurses as the part of community in social relation should be treated fairly and in civilized manner. Therefore, social support is very desirable between an individual and another in handling Covid-19. Sociologically, perception or social construction non Covid-19 pandemic condition today is affected by community's knowledge on the reality occurring. Indonesia actually has social asset to accelerate Covid-19 management and to respond to the social phenomenon occurring amid health crisis [16].

Indonesian people have social capital to accelerate Covid-19 management. In this situation, people have social relations such as empathic bonding, appreciation and respect, thereby creating mutual cooperation and mutual help attitude [17]. In its realization in the field, it can start with integrated team existing involving government, police officer, medical personnel and community element and neighbourhood leader, so that discrimination can be minimized well $[18,19]$. They should invite the community to support and to motivate Covid-19 positive ODP and PDP as well as their family to grow the feeling of mutual cooperation between them. Government and community (people) should have empathy with, motivate, and support them [20, 21]. The priority is now given to maintaining health and cleanliness by following health protocol and government's appeal into this pandemic ends.

Contributing socially by building confidence in healthcare service and facilities and showing empathy to those infected or with symptoms is better than showing social stigma [20]. Government, people, media, and community play an important role in preventing and ceasing Covid-19-related stigma, particularly associated with Chinese and generally Asian people. People should communicate carefully and wisely in social media or other communication platform. Hospital, research institution, university, and other institutions can straighten hoax and facts [22]. Social stigma can occur due to the poor knowledge on Covid-19 (how the disease is transmitted and treated, and how to prevent the infection). 
Accurate information should be disseminated corresponding to the community concerning the affected area, individual and group's vulnerability to Covid-19, treatment, and where people can access treatment and health information.

Amid this pandemic, people then build social construction on the situation they experience. Externalization in this research is the time when social construction begins to be understood. Social construction builds on discourse, reality, and policy prevailing within society [19]. It is inseparable from the community's poor cognition on Covid-19 pandemic. Amid so transparent information channel, people tend to believe more in information based on their emotion thereby overriding the fact or the truth of information itself. As a result, excessive panic will arise before receiving information in detail about Covid-19 pandemic. This condition then make the people easily stigmatizing those considered as vulnerable to this virus chain transmission [23-25].

The externalization stage in this research is indicated with Surakarta people's prior perception on Covid-19, in which they see it as a new disease and have only a little information on it, they are often afraid of what they do not know, and easily connect the fear to others. Objectification process is people's perception on leprosy patients corresponding to people's prior knowledge on Covid-19, and then becomes objective reality. In this objectification process, people's perspectives on Covid-19 positive patients are varying. Their perspective builds on knowledge and experience they got, in which knowledge and experience an individual gets are different from another does.

Internalization stage is indicated with Surakarta people's subjective reality against Covid-19 patients that is different between an individual and another; it is affected by objectification stage they have passed through. Through internalization process, people then construct interpretation or perception on individual or group having ever interacted with this virus or been infected with this pandemic. There is an assumption that they can be infected with Covid-10 pandemic, compelling them to create social distancing later.

\section{Conclusion}

Preventing and ceasing stigma are not difficult to do if all members of community unite and are committed to not disseminating prejudice and resentment against certain group related to Covid-19. Thus, the government attempts to socialize and to campaign for the prevention of stigmatization against Covid-19 patients and their family through various information channels, and all parties should support this attempt. It means that all potencies and resources existing within community should be transformed, including the role of social agents in responding to any form of stigmatizations as the part of an attempt of breaking the Covid-19 pandemic transmission chain. In this situation, the humanity feeling should be prioritized. 


\section{References}

1. CSSE, JHU, Coronavirus COVID-19 Global Cases by the Center for Systems Science and Engineering (CSSE) at Johns Hopkins University (JHU),

https://coronavirus.jhu.edu/map.html (2020).

2. Kementerian Kesehatan Republik Indonesia. Situasi Infeksi Emerging - Info Corona Virus, https://covid19.kemkes.go.id/category/situasi-infeksi-emerging/info-coronavirus/\#.XsHIDMAxXIU (2020).

3. WHO, Coronavirus disease (COVID-19) Pandemic, https://www.who.int/emergencies/diseases/novel-coronavirus-2019 (2020).

4. C. Y. Lin, Social reaction toward the 2019 novel coronavirus (COVID-19), Social Health and Behavior, 3(1), 1, 1-3 (2020).

5. M. T. Hasan, Addressing the COVID-19 related stigma and discrimination: a fight against infodemic in Bangladesh https://psyarxiv.com/qpbj7/ (2020).

6. J. He, L. He, W. Zhou, X. Nie, M. He, Discrimination and Social Exclusion in the Outbreak of COVID-19. International Journal of Environmental Research and Public Health, 17(8), 2933 (2020).

7. V. Thakur, A. Jain, COVID 2019-Suicides: A global psychological pandemic, Brain, behavior, and immunity, https://doi.org/10.1016/j.bbi.2020.04.062 (2020).

8. WHO, Social Stigma associated with COVID-19, https://www.unicef.org/media/65931/file/Social\%20stigma\%20associated $\% 20$ with $\% 20$ the \%20coronavirus\%20disease \%202019\%20(COVID-19).pdf (2020).

9. P. L. Berger, T. Luckmann, D. Zifonun, The Social Construction of Reality, Allen Lane, London (1967).

10. J. W. Creswell, J. D. Creswell, Research Design Qualitative, Quantitative, and Mixed Methods Approaches. $5^{\text {th }}$ Edition, Sage Publications, Thousand Oaks, CA (2017).

11. C. Hewson, D. W. Stewart, Internet research methods, Wiley StatsRef: Statistics reference online, 1-6 (2014).

12. J. Salmons, Cases in online interview research, Sage Publications, Thousand Oaks, CA (2011).

13. J. Salmons, Qualitative online interviews: Strategies, design, and skills, Sage Publications, Thousand Oaks, CA (2014).

14. M. B. Miles, A. M. Huberman, J. Saldaña, Qualitative Data Analysis: A Methods Sourcebook, Sage Publications, Thousand Oaks, CA (2014).

15. H. R. Bernard, A. Wutich, G. W. Ryan, Analyzing Qualitative Data: Systematic Approaches, Sage Publications, Thousand Oaks, CA (2016).

16. Z. Hu, Z. Yang, Q. Li, A. Zhang, Y. Huang, Infodemiological study on COVID-19 epidemic and COVID-19 infodemic, https://www.researchgate.net/profile/Zhiwen_Hu/publication/339501808 Infodemiolo gical study on COVID-19 epidemic and COVID19 infodemic/links/5e78a0834585157b9a547536/Infodemiological-study-on-COVID19-epidemic-and-COVID-19-infodemic.pdf (2020).

17. H. Xiao, Y. Zhang, D. Kong, S. Li, N. Yang, Social capital and sleep quality in individuals who self-isolated for 14 days during the coronavirus disease 2019 (COVID-19) outbreak in January 2020 in China, Medical science monitor: international medical journal of experimental and clinical research, 26, e923921-1 (2020). 
18. S. Krier, C. Bozich, R. Pompa, M. R. Friedman, Assessing HIV-Related Stigma in Healthcare Settings in the Era of the COVID-19 Pandemic, Pittsburgh, Pennsylvania, AIDS and Behavior, 1 (2020).

19. C. H. Logie, J. M. Turan, How Do We Balance Tensions Between COVID-19 Public Health Responses and Stigma Mitigation? Learning from HIV Research, AIDS and Behavior, 1-4 (2020).

20. P. D. Lunn, C. A. Belton, C. Lavin, F. P. McGowan, S. Timmons, D. A. Robertson, Using Behavioral Science to help fight the Coronavirus, Journal of Behavioral Public Administration, 3(1) (2020).

21. G. Stankovska, I.Memedi, D. Dimitrovski, Coronavirus COVID-19 disease, mental health and psychosocial support, Society Register, 4(2), 33-48 (2020).

22. J. M. Kim, Y. S. Chung, H. J. Jo, N. J. Lee, M. S. Kim, S. H. Woo, S. Park, J. W. Kim, H.M. Kim, M. G. Han, Identification of Coronavirus Isolated from a Patient in Korea with COVID-19, Osong Public Health and Research Perspectives, 11(1), 3 (2020).

23. D. P. Bruns, N. V. Kraguljac, T. R. Bruns, Journal of Transcultural Nursing, 1043659620917724 (2020).

24. C. S. Ho, C. Y. Chee, R. C. Ho, Mental health strategies to combat the psychological impact of COVID-19 beyond paranoia and panic, Ann Acad Med Singapore, 49(1), 13 (2020).

25. C. H. Logie, Lessons learned from HIV can inform our approach to COVID-19 stigma, Journal of the International AIDS Society, 23(5) (2020). 